\title{
Edukasi Pola Makan yang Baik dan Bergizi Pada Warga dimasa Pandemi Covid 19
}

\author{
Suhermi $\mathbf{S}^{1}$ *, Fatma Jama ${ }^{2}$, Rahmawati Ramli ${ }^{3}$ \\ 1,2,3 Program Studi Pendidikan Ners, Universitas Muslim Indonesia
}

\section{*Suhermi S.}

Email: suhermi.suhermi@umi.ac.id Alamat: JIn.Urip Sumoharjo KM 5, Makassar.

\section{History Artikel}

Received : $26-08-2021$

Accepted: $30-08-2021$

Published: $31-08-2021$

\begin{abstract}
Abstrak.
Zat-zat yang terkandung di dalam makanan dan minuman yang kita konsumsi membawa pengaruh terhadap sistem tubuh. Maka tidak salah bila dikatakan bahwa pola asupan makanan menentukan status kesehatan seseorang. Namun, pandemi Covid-19 telah menyebabkan terjadinya perubahan pola makan sebagian orang. Perubahan pola makan tersebut dikaitkan dengan adanya kecemasan dan ketakutan yang dialami sebagian orang yang menyebabkan berkurangnya keinginan atau motivasi untuk makan dan berkurangnya kenikmatan saat makan. Padahal, salah satu upaya yang dapat kita lakukan agar dapat bertahan di saat pandemi Covid19 adalah dengan menerapkan pola makan yang sehat. Tujuan Kegiatan ini adalah untuk meningkatkan pemahaman masyarakat mengenai isi piringku. Metode kegiatan yaitu ceramah, diskusi dan demonstrasi Hasil dari kegiatan pengabdian kepada masyarakat ini adalah Peserta merespon dengan baik tentang penyuluhan pola makan yang sehat dan bergizi selama masa Pandemi Covid 19, peserta mengikuti kegiatan dari awal sampai akhir. Peserta mampu menyebutkan makanan yang bergizi dan Peserta mampu mendemonstrasikan cuci tangan dengan 6 langkah yang benar
\end{abstract}

Kata Kunci: Pola Makan; Sehat ; Bergizi ; Covid 19

\begin{abstract}
Substances contained in the food and drinks we consume have an effect on the body's system. So it is not wrong to say that the pattern of food intake determines a person's health status. However, the Covid-19 pandemic has caused a change in the diet of some people. Changes in eating patterns are associated with the anxiety and fear experienced by some people around the world. In addition, emotional disturbances such as fear and sadness lead to reduced desire or motivation to eat and reduced enjoyment of eating. In fact, one of the efforts we can do in order to survive during the Covid-19 pandemic is to apply healthy eating. The purpose of this activity is to increase public understanding of the contents of my plate. The research method is lectures, discussions and demonstrations. The results of this community service activity are: Participants respond well to counseling on healthy and nutritious eating patterns during the Covid 19 Pandemic, participants participate in activities from beginning to end. Participants are able to mention nutritious food and Participants are able to demonstrate hand washing with 6 correct steps
\end{abstract}

Keyword: Dietary habit; Healthy; Nutritious ; Covid 19 


\section{Pendahuluan}

Makanan adalah kebutuhan pokok makhuk hidup yang dibutuhkan setiap saat untuk kelangsungan hidup dan memberikan energi pada setiap harinya. Jika kita para manusia terutama tidak makan seharian saja kita tidak akan memiliki tenaga untuk beraktifitas dan lemas seharian. Sehat berawal dari "isi piringku". Zat-zat yang terkandung di dalam makanan dan minuman yang kita konsumsi membawa pengaruh terhadap sistem tubuh. Maka tidak salah bila dikatakan bahwa pola asupan makanan menentukan status kesehatan seseorang (HUMAS UNS, 2020).

Salah satu kebutuhan dasar manusia adalah kebutuhan pangan, merupakan kebutuhan yang sangat penting karena menyangkut makanan dan minuman yang dibutuhkan oleh manusia agar tetap hidup. Pentingnya pangan bagi manusia merupakan alasan ditetapkannya hari pangan nasional yang diperingati setiap tanggal 16 September setiap tahun. Melalui peringatan hari pangan nasional, kita senantiasa diingatkan untuk melihat keanekaragaman sumber pangan di sekitar kita dan memanfaatkannya untuk memenuhi kebutuhan kita akan pangan secara tepat, salah satunya dengan mengatur pola makan agar kita senantiasa sehat (Kemenkes,2020).

Namun, pandemi Covid-19 telah menyebabkan terjadinya perubahan pola makan sebagian orang. Perubahan pola makan tersebut dikaitkan dengan adanya kecemasan dan ketakutan yang dialami sebagian orang di seluruh dunia. Selain itu, gangguan emosional seperti ketakutan dan kesedihan menyebabkan berkurangnya keinginan atau motivasi untuk makan dan berkurangnya kenikmatan saat makan (Yanti, B., \& Priyanto, H. 2020). Padahal, salah satu upaya yang dapat kita lakukan agar dapat bertahan di saat pandemi Covid19 adalah dengan menerapkan makan yang sehat (Probhoyekti, 2020).

Pola makan yang sehat akan menjamin sistem kekebalan tubuh tetap kuat, sehingga membantu menahan serangan virus. Setiap makanan yang kita konsumsi akan memberikan pasokan nutrisi bagi tubuh kita terutama protein dan vitamin yang mampu melindungi tubuh dari penyakit. Protein menyumbang sekitar $75 \%$ untuk sistem kekebalan tubuh dan berfungsi untuk mengganti sel yang rusak, membentuk hormon dan menolak virus yang masuk, sedangkan vitamin $A$ dan vitamin $C$ bermanfaat untuk melindungi kulit, lambung, dan usus sehingga virus tidak dapat menginfeksi tubuh. (Pane, 2020)

Makan bukan untuk sekadar kenyang, tetapi perlu memenuhi kebutuhan nutrisi dan menjaga kesehatan tubuh. Karena itu, masyarakat hendaknya memahami pedoman gizi seimbang yang saat ini disebut dengan istilah "Isi piringku". Dalam satu porsi sajian, sayur-sayuran dan buahbuahan hendaknya memiliki porsi separuh bagian piring setiap makan. Sementara itu, separuh bagian priring lainnya diisi dengan makanan pokok sumber karbohidrat dan lauk-pauk yang banyak mengandung protein (Kemenkes, 2020).

Konsep 4 sehat 5 sempurna sudah sangat awam bagi masyarakat Indonesia sebagai acuan pola makan sehat. Namun seiring dengan perkembangan ilmu gizi, konsep tersebut sudah kurang relevan dengan pola makan sehat masyarakat saat ini. Dalam perkembangan ilmu gizi yang baru, pedoman "4 Sehat 5 Sempurna" berubah menjadi pedoman gizi seimbang yang terdiri dari 10 pesan tentang menjaga gizi. Dari 10 pesan tersebut, dikelompokan lagi menjadi empat pesan pokok yakni pola makan gizi seimbang, minum air putih yang cukup, aktivitas fisik minimal 30 menit per hari, dan mengukur tinggi dan berat badan yang sesuai untuk mengetahui kondisi tubuh. Sebagai pedoman baru pola makan gizi seimbang Kementerian Kesehatan memperkenalkan slogan baru yaitu "Isi Piringku"(Agustine, 2021).

\section{Metode}

Metode Pelaksanaan pengabdian ini meliputi : Ceramah, Tanya Jawab, Diskusi dan Demonstrasi. Tahap ini dimulai dari Tahap I persiapan yaitu membuat surat tugas dari instusi untuk kegiatan pelaksanaan pengabdian di Desa Sokkolia, 
Kab.Gowa, dilanjutkan dengan persiapan alat dan instrument, membagikan kuesioner pre test kepada warga Desa Sokkolia.. Pada pelaksanaan diawali dengan persentasi materi tentang "Isi Piringku" (Nasi, Sayur,ikan dan buah). kegiatan penyuluhan dilakukan selama 45 menit selain itu materi tentang cara meningkatkan pola hidup sehat juga disampaikan kepada warga. Tahap akhir post test pembagian kuesioner menilai evaluasi tingkat pengetahuan warga.

Bentuk partisipasi mitra berkoordinasi dengan warga dalam memfasilitasi pelaksanaan kegiatan yang akan dilakukan termasuk mengkoordinasi warga, serta menyiapkan tempat untuk pelaksanaan kegiatan

Setelah program ini selesai,diharapkan dapat meningkatkan pengetahuan masyarakat tentang program germas "Isi Piringku" serta memberi pengetahuan kepada masyarakat bagaimana menjaga pola makan baik dan sehat selama pandemic sehingga dapat merubah sikap dan perilaku yang sesuai dengan isi piringku dan dapat menerapkannya dikehidupan sehari-hari

\section{Hasil dan Pembahasan}

Kepala dusun Sokkolia membantu memfasilitasi kami dalam memberikan edukasi kepada warga mengenai isi piringku. Memotifasi warga agar mengikuti kegiatan dengan baik. Sebanyak 20 warga yang mengikuti kegiatan ini dengan latar pedidikan dan pengetahuan sangat minim. Para warga berkumpul di rumah bapak kepala dusun yang diarahkan oleh para anggota dan mahasiswa.. Kegiatan diawali dengan pemeriksaan kesehatan.

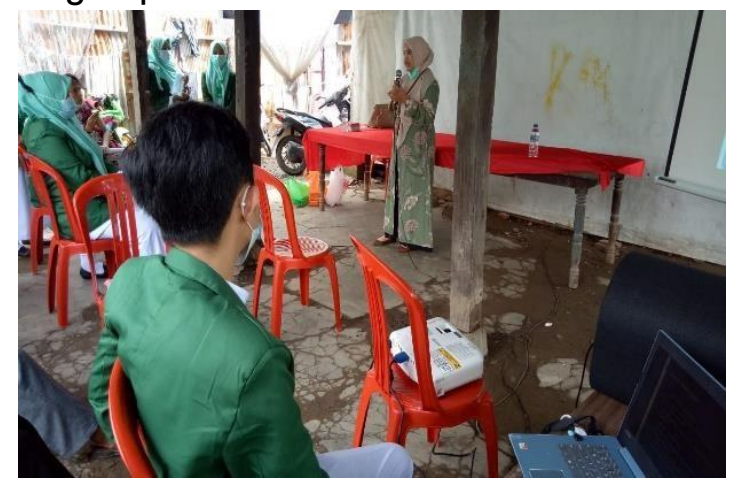

Gambar 1. Penyuluhan kesehatan Desa dan Mahasiswa
Setelah tim pengabdi melakukan pemeriksaan kesehatan, selanjutnya tim memberikan edukasi tentang Definisi makanan sehat Mengenal "Isi Piringku" Perbedaan "4 Sehat 5 Sempurna" dan "Isi Piringku" Jenis-jenis makanan bergizi dengan menggunakan poster maupun

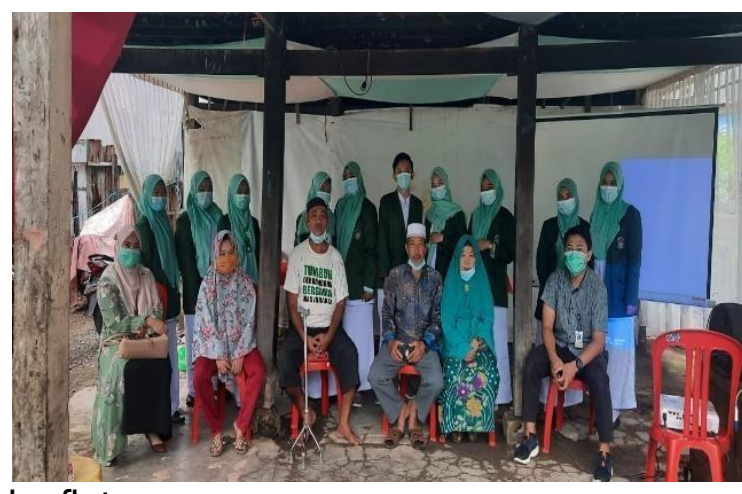

leaflet

Gambar 2. Foto Bersama dengan Kepala Desa

Masyarakat yang kebanyakan lansia merespon dengan baik tentang penyuluhan pola makan yang sehat dan bergizi selama

masa Pandemi Covid 19. Lansia mampu menyebutkan makanan bergizi yang mudah ditemui disekitar lingkungan mereka sehingga mengubah asumsi masyarakat bahwa makanan yang sehat dan bergizi itu mahal dan susah didapatkan.

Selain itu, masyarakat diajarkan juga cara cuci tangan yang benar dengan 6 langkah. Agar masyarakat tidak hanya terjaga dari kebersihan makanannya tapi juga terjaga dari kebersihan fisiknya. Seluruh peserta mengikuti kegiatan dari awal sampai akhir.

\section{Kesimpulan}

Peserta merespon dengan baik tentang penyuluhan pola makan yang sehat dan bergizi selama masa Pandemi Covid 19. Pengetahuan peserta meningkat mengenai makanan yang bergizi. Sebaiknya pemerintah dan pihatk terkait meningkatkan upaya promosi kesehatan dalam rangka meningkatkan pengetahuan masyarakat tentang program germas "Isi Piringku"

\section{Daftar Pustaka}

Agustine, S. (2021). Memenuhi Gizi Seimbang dengan Panduan Piring Makan - Alodokter. Retrieved from 
https://www.alodokter.com/memenuhigizi-seimbang-dengan-panduan-piringmakan

HUMAS UNS. (2020). Pola Makan Sehat dan Bergizi untuk Meningkatkan Imunitas saat Terserang Covid-19 Universitas Sebelas Maret. Universitas Sebelas Maret. Retrieved from https://uns.ac.id/id/uns-opinion/polamakan-sehat-dan-bergizi-untukmeningkatkan-imunitas-saat-terserangcovid-19.html

Kemenkes. (2020, Juli 21). Covid-19. Dipetik Juli 21, 2020, dari Kementrian Kesehatan Republik Indonesia: covid19.kemkes.go.id

Kemenkes RI. (2020, 23 April). Makanan sehat selama Covid 19. Dipetik Juli 21, 2020, dari Kementirian Kesehatan Republik Indonesia: http://www.padk.kemkes.go.id/article /read/2020/04/23/21/ 19.html

Nareza, M. (2020, Mei 27). COVID-19 Lebih Berbahaya bagi Lansia di Atas 70 Tahun. Dipetik Mei 21, 2020, dari Alodokter: https://www.alodokter.com/covid-19lebih-berbahaya-bagi-lansia-di-atas70-tahun

Pane, M. D. C. (2020). COVID-19 - Gejala, penyebab dan mengobati - Alodokter. ALODOKTER Kementrian Kesehatan Republik Indonesia, p. 1. Retrieved from https://www.alodokter.com/covid19

Probhoyekti, D. (2020). Panduan Gizi Seimbang COVID-19.pdf (p. 30). p. 30.

Yanti, B., \& Priyanto, H. (2020). Sosialisasi Waspada Infeksi Corona Virus Pada Lansia di Panti Jompo Rumah Sejahtera Geunasih Sayang, Dinas Sosial Aceh. Jurnal Pengabdian Masyarakat Volume 3 Nomor 1, 6774. 